POLITYKA ENERGETYCZNA - ENERGY POLICY JOURNAL

$2020 \star$ Volume $23 \uparrow$ Issue $1 \uparrow 49-64$

DOI: $10.33223 / \mathrm{epj} / 119074$

\title{
Issues related to the development of electromobility from the point of view of Polish utilities
}

ABSTRACT: At present, electromobility is a very dynamically developing segment and at the same time has many unknowns that enterprises that want to develop this area in their structures have to face. This article aims is to show the difficulties of electromobility development from the perspective of Polish energy groups which are closely related to this area, especially considering the obligations imposed on energy companies by the legislator. The electrification of transport has become a reality and in order to use its potential to develop new services or implement innovations and new technologies, it is necessary to identify development barriers and prepare a response plan. The authors of the article decided to show the formal and legal implications for the development of electromobility in Poland in first order, and then examine the development strategies of Polish energy groups in terms of electromobility and indicate explored areas related to it. The next section focuses on identifying the main barriers to the implementation of business models, classifying them according to the following factors: economic, operational, technical, social and legal. This presentation of the problem allows for an in-depth recognition of the issue and realizing that in order to achieve the goals set by the Legislator, close cooperation of all stakeholders is necessary both at the national and local level,

$\triangle$ Corresponding Author: Wojciech Drożdż; e-mail: wojciech.drozdz@usz.edu.pl

${ }^{1}$ Logistic Department, University of Szczecin, Poland; ORCID iD: 0000-0001-5915-546X; e-mail: wojciech. drozdz@usz.edu.pl

2 ENEA SA, Poland; e-mail: paulina.szczerba@enea.pl

3 ENEA Innowacje Sp. z o.o., Poland; e-mail: dawid.kruszynski@enea.pl

2020. The Author(s). This is an open-access article distributed under the terms of the Creative Commons Attribution-ShareAlike International License (CC BY-SA 4.0, http://creativecommons.org/licenses/by-sa/4.0/), which permits use, distribution, and reproduction in any medium, provided that the Article is properly cited. 
while engaging energy groups, financial companies, electric vehicle manufacturers, and above all local government units in these activities.

KEYwORDs: alternative fuels, energy sector, electromobility, clean transport

\section{Introduction}

Poland, as well as the other EU member states, is participating in the next transformation of the automotive market. The electrification of transport has become the fact generating significant operating and environmental benefits. It is an opportunity to boost innovation and improve the quality of life. In recent years, we have observed a strong technology advancement and business trends corresponding to environmental and climate conditions. New solutions, such as the development of electromobility services, change the previous market competition set up and significantly affect the decoupling from fossil fuels. Thus, innovation and modern technologies have their strong influence on and stimulate the development of the power sector.

The aim of this article is to indicate the difficulties encountered in the development of electromobility in Poland. The study focuses on the perspective of Polish energy groups and identifies the difficulties from their perspective. The implemented measures supporting electromobility are an opportunity for the development of the Polish power sector. However, it should be borne in mind that the promotion of the trend and prepared legislative framework are not sufficient to effectively implement the proposed solutions. The development of electromobility is primarily a joint action of Polish energy groups, the central government administration, local government units and other business entities in order to achieve synergy.

The consistently growing cities are major population centers and it is crucial to provide efficient means of transport to support everyday life of a metropolis. The society demands effective transportation and a clean environment. So far, these two issues seemed to be mutually exclusive. However, advanced research and technological advancement have created new opportunities. Electromobility, the foundation of which rests on zero-emission means of transport, improves the comfort and quality of life in cities. It is also an opportunity to boost economic growth.

The Ministry of Energy defines electromobility as one of the key action areas. The law has been recently extended with a number of adjustments to promote low- and zero emission vehicles - both in public and individual transport. The Urban Mobility Package is an example of the first comprehensive approach to electromobility. The Package contains such documents as: The Electromobility Development Plan, National Policy Framework for the Development of Alternative Fuel Infrastructure, and the Electromobility and Alternative Fuel Act (January 11, 2018). The Package has not only become the legal basis for the development of electromobility in Poland, but it also provides an opportunity to apply for grants through financial instruments offered by the Low-emission Transport Fund. This document sets foundations 
for the construction and development of the electromobility ecosystem, involving producers, operators and users of transport. It turns out, however, that despite a strong support from the state, electromobility continues to face barriers to development, especially from the point of view of Polish utilities.

\section{Formal and legal conditions of the development of electromobility in Poland}

The Polish Electromobility Development Plan is the response to global trends and contains analysis addressing statistics regarding the increase in the number of electric vehicles. It also provides for a specific support in this economic sector. Polish utilities are required to meet a number of obligations arising from policy documents on electromobility.

\subsection{The Responsible Growth Strategy until 2020 (with prospects toward 2030)}

The development of electromobility is one of key pillars of the Responsible Growth Strategy until 2020 with Prospects Toward 2030 ("The Strategy") (The Ministry Development Funds and Regional Policy 2019). The Strategy, as one of the most important policy documents, which formulates the new vision and the model for the development of the country in response to challenges faced by the Polish economy in the mid- and long-term economic policy and its main goal is to "create conditions conducive to growth income in Poland while increasing social, economic, environmental and territorial cohesion". In fact, the Strategy changes the structure of the economy to make it more innovative, while, at the same time, it makes use of available resources, including human capital and tangible assets. It is worth noting that in the context of this document, a particular emphasis is put to increase the responsibility of the state for economic, social and territorial processes.

\subsection{The Electromobility Development Plan}

Yet another important document determining the development of electromobility in Poland is the Electromobility Development Plan (the „Plan”). The Plan defines the three main objectives: create conditions for the development of electromobility in Poland (through expansion 
of charging infrastructure and incentives to purchase electric vehicles), develop the industry and stabilize the grid by integrating vehicles with the grid (The Ministry of State Assets 2019). According to the Ministry of State Assets, it is essential to implement actions specified in the Plan in parallel in five areas: raising the awareness of prospective users, developing a system of incentives to use electric vehicles, developing production in the electromobility segment, adjusting regulations and improving the power grid. The plan touches on issues associated with support to the entire electromobility ecosystem, among others, by determining the boundaries of the new economic system, boosting demand for alternative fuels, in particular for the benefit of urban transport, extending special "care" of innovative companies which develop the infrastructure and finally, the drivers themselves (Kurzempa 2018). The implementation of the plan is divided into three stages. The first preparatory stage was scheduled in 2016-2018. The second phase (2019-2020), involving directly previously launched pilot projects, is designed to draw up a list of good practices in social communication. And the final stage in 2020-2025 seeks to amend the attitude to electromobility. It is expected that it should respond to challenges brought by the new reality (The Ministry of State Assets 2019). This plan is going to be implemented by a number of institutions - both central and local. Directly involved parties include the Minister of Entrepreneurship and Technology, the Minister of Investment and Development, the Minister of Finance, and the Polish Development Fund, Polish Industrial Development Agency, as well as local governments.

\subsection{National policy framework for alternative fuel infrastructure}

The National Policy Framework for Alternative Fuel Infrastructure (The Ministry of State Assets 2018) is related to the Strategy. It assesses the condition and possibilities for the development of the alternative fuels market in the transport sector, general and specific national targets for the development of charging infrastructure for electric vehicles and natural gas (compresses natural gas (CNG) and liquid natural gas (LNG)) infrastructure, as well as the market for infrastructure vehicles using these fuels. It also shows support instruments to achieve the above mentioned objectives, as well as those necessary to implement the Electromobility Development Plan, and a list of agglomerations and highly populated areas in which public charging stations for electric vehicles and CNG stations will be established. The document provides that in 2020, 6 thousand slow charging stations and 400 fast charging stations with an estimated service capacity of at least 50 thousand electric vehicles, will be established in 32 selected agglomerations. The National Framework provides for the construction of 70 compressed natural gas (CNG) stations for the estimated number of 3 thousand vehicles using the fuel. It is estimated that by 2025, the number of electric vehicles will reach 1 million, whereas the number of CNG vehicles should be 54 thousand in Poland. At the same time, 32 charging points are going to be developed along Trans-European Transport Network (TEN-T). The document foresees that at least 3 thousand LNG vehicles will be in operation and 14 LNG stations will be built within the TEN-T. The 
implementation of objectives will allow innovation and clean transport to be promoted in Poland and the program itself is consistent with the Electromobility Development Plan.

\subsection{Electromobility and Alternative Fuels Act of January 11, 2018}

The primary objective in the Electromobility and Alternative Fuels Act of January 11, 2018 is to stimulate the development of electromobility and promote alternative fuels in the transport sector (The Ministry of State Assets 2019). The act is a key regulation defining the electromobility framework in the country. It introduces the most important legal definitions and regulates the functioning of key institutions. The provisions of the Act support operations undertaken by private businesses (Kurzempa 2018). The Act covers issues related to the construction and maintenance of charging infrastructure for public transport and the necessary steps to be taken to connect charging points to the grid, as well as the modernization, development and extension of the grid. For the first time, the Act has introduced and explained the concept of the electric vehicle. The document defines the rules for the deployment, development and operation of charging infrastructure in public transport, especially in large agglomerations, densely populated areas and also along Trans-European Transport Corridors. The Act also defines the complete development path and the construction of public charging stations and natural gas stations. According to the Act, procedures underlying the development of charging infrastructure for electric vehicles and gas infrastructure were made separate. The charging of vehicles has become a new kind of business - the mere charging is not considered as the sale of electricity in the meaning of the Energy Law of April 10, 1997 and, as such, does not require a concession (Krotoski 2018). As mentioned above, the first stage of developing charging stations was scheduled in 2018-2019. At that time, the infrastructure should have been developed based on market principles with public support. In case the assumed number of charging stations in municipalities that meet requirements laid down in the law is not reached, municipalities are obliged to develop their development plans for the missing charging infrastructure. The construction of missing charging stations will be the responsibility of the distribution system operator (DSO). Development plans are to be drawn up only for municipalities of a population of at least 100 thousand with at least 60 thousand vehicles registered and on average 400 vehicles per 1000 inhabitants. According to Article 32, the Act requires the Director of the National Roads and Motorways Authority to develop a public charging and natural gas stations deployment plan along the core TEN-T network for a minimum period of 5 years. According to Article 34 paragraph 1 of the Act, central authorities should ensure that the fleet of vehicles in use in a relevant public office or institution should consists of at least $50 \%$ of electric vehicles. Article $69-70$ of the Act establishes the Alternative Fuel Infrastructure Register which main purpose is to collect information about electric vehicle users and electrical charging and gas filling stations. The register should be based on IT systems of the Office of Technical Inspection and enable quick access to information to facilitate the use of alternative fuel vehicles. New regulations (Articles 39-40 of the Act) enable municipalities 
to establish clean transport zones with traffic restricted to electric, hydrogen and natural gas vehicles only.

\subsection{Low-Emission Transport Fund}

The Clean Transport Package provides for the establishment of the Low-Emission Transport Fund ("LTF") (Witkowski and Wiśniewski 2018). It is established based on the Act of June 6. 2018 Amending the Biocomponent and Liquid Biofuel Act and Certain Other Laws, and it is managed by the National Fund for Environmental Protection and Water Management. Its primary purpose is to finance projects related to the development of electromobility and transport based on alternative fuels (Innogy 2017).

\section{Statutory obligation and the activity of power utilities in Poland}

In its Article 60, the Electromobility and Alternative Fuels Act defines the obligation of municipalities to expand charging station infrastructure for electric vehicles. In case the minimum number of public charging points provided for in the Act is not reached, the mayor is required to draw up the Public Charging Station Plan by March 15, 2020.

A draft of the plan is then forwarded to the Distribution System Operator ("DSO") relevant for the area where public charging stations are to be developed. The next step of the procedure is to informm through the DSOm that a draft plan has been agreed and transfer a connecting schedule setting out technical and economic conditions for connecting public charging stations, including planned connection dates. Then, the mayor should apply to the President of the Energy Regulation Office ("URE President") to appoint the utility company which will play the role of the Charging Station Operator ("CSO") responsible for the management, safety, operation, maintenance and repair of public charging stations, and the Charging Service Provider (CSP). The URE President, by his administrative decision, should appoint the CSO and CSP involved in power trading to sell electricity to the largest possible number of end users connected to the power grid in the territory covered by the CSO. According to the Act, within one year of assuming the role of the operator station by the utility company designated by the URE President, the DSO which built a public charging station should implement a procedure for selecting the CSO.

The main obligations of the SCO, designated by the URE President, include: the management, security, operation, maintenance and repair of a public charging station and provision of software that allows for the connection and charging of electric and hybrid vehicles and for data 
about the availability of a charging point and the price for charging to be transferred to the Alternative Fuels Infrastructure Register. The CSP provides charging service and keeps the accounts for the service, as well as provides information about the price and conditions of the service at its website.

\section{Electromobility in development strategies of Polish utility companies}

The analysis of power utilities shows that apart from their core activity related to the distribution and sales of electricity, they are looking for new areas of "operation" and development, e.g. electromobility. It should be noted, however, that the key issue in this area is the return on projects developing new business lines of electric cars and charging infrastructure. This has been confirmed by the decision of Vozilla, a Wroclaw-based electrical carsharing operator (Public Transport 2020) to terminate its operation, as well as data published by PKN Orlen indicating the already developed infrastructure has been used by very few users (PKN Orlen 2020).

Since DSOs have a statutory obligation to develop charging stations for electric vehicles, power utilities are forced to find new business models to implement the infrastructure and reduce losses while focusing on future returns.

A practical approach to the business model (Drożdż 2018) shows that the utility company should look for synergies between its resources and knowledge of the market and the development of target models to successfully compete on the market. The aim is clear and the same for each entity, namely to generate profits within a specified time frame.

Analysis of development strategies by Polish power utilities shows that, instead of creating completely new business models, an appropriate solution from the point of view of the utilities is to find innovative business solutions which combined with the existing model and know-how can make those utilities more efficient. The development of new models should be based on the following:

$\checkmark$ new (also private) charging networks with an extended infrastructure to engage drivers when their vehicles are being charged,

$\checkmark$ cooperation with those already present on the market involved in the extension of the network and making specific locations more attractive, e.g. close to restaurants, shopping malls, and car showrooms,

$\checkmark$ making use of regulations establishing clean transport zones,

$\checkmark$ development which translates into branding, e.g. strengthening positive communication with institutions and state administration (Rudyszyn 2019),

$\downarrow$ promotion of the sharing economy by the development of transport systems shared by larger numbers of people, i.e. e-carsharing (PWC 2018) or microelectromobility (scooters, kick scooters, bicycles), 
$\checkmark$ investment by fuel and power companies in startups based on promising business ideas and know-how, while they are still in the early phase of their development (Bernaciak 2019).

The development of electromobility that involves a dynamic, rapid increase in the number of electric vehicles appears to be one of the biggest opportunities for utility companies. Despite the fact that the Polish electromobility market is fledgling and the use of electric vehicles is indeed very limited in the scale of the Polish automotive sector, we can observe some progress and interest among the largest operators. It is worth noting the increase in the number of electric cars used in Poland as shown in the graph below (Based on: European Alternative Fuels Observatory).

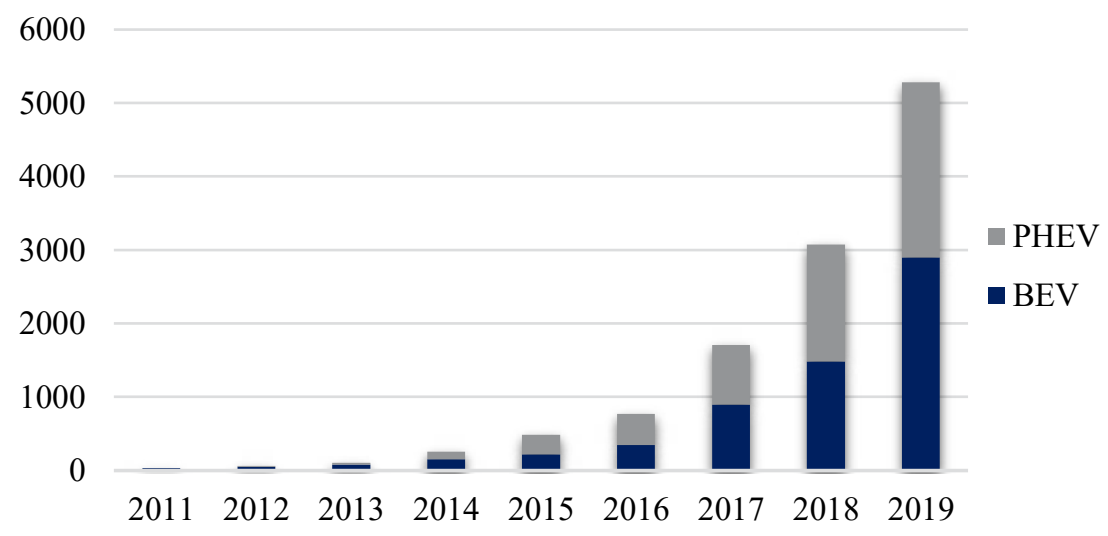

Fig. 1. Electric cars in Poland

Rys. 1. Samochody elektryczne w Polsce

The presented data indicates a rapid growth of the number of individual electric vehicles. Every year, the number of BEV (battery electric vehicle) and PHEV (plug-in hybrid electric vehicle) vehicles has been growing as well. The indicator showing the increase in the number of vehicles year-to-year is between 1.56-2.50. Since we may expect that the trend is going to continue in upcoming years, the demand for services associated with "electric vehicles" will gradually increase as well, and such growth may be the driver attracting large market players.

While examining the operation of Polish utility companies, it is worth noting that electromobility is included in development strategies and presented in the integrated annual reports.

The example of a selected power utilities shows some activity in the area as a result of statutory obligations. Effects of the above will be seen in streets of Polish cities within DSO operation areas at the end of 2020. Among other things, Electromobility (Enea Group 2019) has been a part of the Enea Capital Group Development Strategy until 2030 with perspective towards 2035. Enea has been committed to the initiative and so are four other energy groups in the country. Enea, a key supplier of electricity in central and western Poland, has been rapidly growing in this particular segment. They have already started the construction of a charging station network. 
Additionally, together with the Polska Grupa Energetyczna (PGE) and Tauron, Enea intends to integrate specialist electric vehicles into its fleet (Money.pl 2019). The document, signed by the largest operators in the country, covers cooperation in designing and manufacturing of electric vehicles by Autosan, the Polish bus manufacturer. In addition to the internal development of their specialist vehicle fleets, PGE (with ENERGA) has just made an agreement on establishing a special purpose vehicle (SPV) Electromobility Poland to manufacture the first Polish electric passenger vehicle.

The development of electromobility provides an opportunity to develop new services, for example carsharing. In Germany carsharing has been offered by 226 providers, while in Poland only 11 businesses provide such services to approximately 4,000 customers (Besa 2020). Polish providers also include power utility companies.

In the Polish carsharing segment, particular attention should be paid the percentage of electric vehicles, since they represent approximately $17 \%$ of the total market (Mobile City and Smartride 2019). E-carsharing created by the Innogy energy group in Warsaw in 2019 had a strong impact on the market. Citizens of the capital city will eventually have access to 500 electric BMW i3 and i3s (Innogy 2019), which are gradually being delivered to the city. The operation of the fleet is supported by charging stations ( 36 semi-fast public chargers and 30 fast charging stations). Apart from Warsaw, e-carsharing is also offered in Katowice, where Tauron Polska Energia offers 20 electric cars by Volkswagen, BMW, Nissan and Renault (Tauron Group 2018). Both in the case of Innogy and the Tauron Group, their strategic partner is ING Bank Śląski. We may assume that the the cooperation of major players on the market (energy, finance and automotive sectors) may secure success for the electromobility project and tangible economic benefits. If acting individually, companies are exposed to excessive risk. E-carsharing has also been developed by PGE Nowa Energia which scaled up their pilot project ( 5 electric cars in Siedlce) into a business operation by investing in 4Mobility, an already existing market operator (Derski 2019).

To sum up the activities of Polish energy groups in the field of electromobility development, a visible increase in interest in this area can be observed. Enterprises are trying to find synergies between implemented projects regarding new business areas in the field of electromobility, and statutory obligations that have been imposed on them. Future transport will be electric, so the energy industry will have a real and visible impact in this area.

\section{Major barriers to business models}

One of the main barriers to the development of electromobility is the shortage of electric vehicles on Polish roads. Factors particularly affecting the change of the trend may include (TOR 2017):

$\checkmark$ the introduction of increasingly stringent emission standards which translate into the increase in the cost of adjusting traditional combustion engines, 
- gradual decrease in the cost of batteries for electric vehicles bringing prices of alternative vehicles closer to conventional ones,

$\checkmark$ wider range of electric vehicles offered by manufacturers,

$\checkmark$ combating smog at the local government level to shift to greener transportation.

Barriers to the implementation of electromobility business models can be divided into five main groups: economic, operation, technical, social and legal. Each of these areas has a major impact on the development of electromobility in companies and they are interdependent.

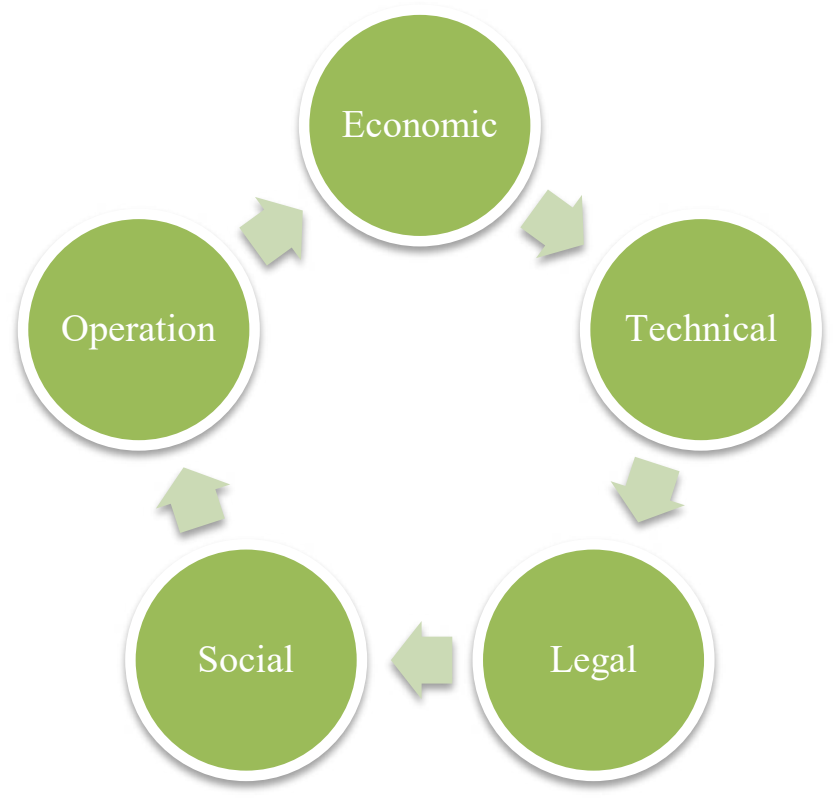

Fig. 2. Main groups of barriers to the implementation of electromobility business models

Rys. 2. Główne grupy barier implementacji modeli biznesowych z zakresu elektromobilności

\subsection{Economic factors}

Mainly economic factors include:

$\checkmark$ high investment cost of building of charging stations and expansion of the distribution network, as well as distribution tariffs (Cire.pl 2018),

$\checkmark$ financial resources to be attracted for the construction of charging infrastructure and the purchase of electric vehicles; the government established the Low-Emission Transport Fund. It should be noted, however, that already at the implementation stage we see certain inaccuracies as regards the planned compensation subject to reduction even before they become 
effective (The European Copper Institute 2020). The problem shows certain economic issues (entrepreneurs have less funding to develop their fleets) and legislative instability,

$\checkmark$ fines for failure to respect the obligation to build a minimum number of charging stations by OSDs as imposed by the amendment of the Act of July 2018,

$\checkmark$ free charging stations made available by the competition during the transition period; It is obvious that this may lead to the decrease in the number of customers using existing charging stations operated by the entity concerned.

\subsection{Operating factors}

The rate of charging infrastructure development should be correlated with the growth of the number of electric vehicles to reduce losses due to the shortage of charging station users (Chojnacki 2020) (this has been confirmed by Rafał Czyżewski, the President of Board of GreenWay Polska: "If OSDs invested in the expected number of charging stations by the end of 2020, i.e. 6.4 thousand, they would stay unused, as it happens with the majority of already built charging stations"). It must also be noted that according to statutory requirements, until the end of 2020 , DSOs are obliged to build more than 6,000 public charging stations for electric vehicles (Szydłowski 2018). From an operational point of view, this issue translates into the need to cover financial losses associated with the maintenance of new infrastructure while at the same time having too few customers to keep it running.

While planning the construction of charging infrastructure, the location of charging stations should be considered crucial. Three main groups of suitable locations can be distinguished: the vicinity of service and public facilities (office buildings, shopping malls, restaurants, city centers etc.), the main transport routes (highways, expressways etc.) and housing estates (housing cooperatives, multi-family buildings, gated communities etc.)

Apart from the location of a charging station, the target group of customers is very important, and they can be divided into regular individual customers, fleet customers, one-off customers.

\subsection{Technical factors}

In the future, the major barrier to scale-up the development of electromobility in the country includes issues pertaining to the National Grid (Kłos 2020). The current grid architecture shows some shortages which the Polish energy sector will have to face in the years to come. Firstly, these problems apply to transmission and distribution networks, which will have to continuously and, more importantly, safely secure the energy supply for the national economy. The rapid development of electromobility will have to be matched with continued improvement of the grid to ensure a sufficient reliability of the power supply. 
With the further development of electromobility, we should also ensure the possibility of the integration between vehicles and the grid, i.e. V2G technology (Vehicle to Grid) (PSPA 2018). The current market situation should be thoroughly examined. A modern economy should be able to combine electromobility and efficient operation of the grid. However, at the first stage of infrastructure development (statutory obligation) obligated parties cannot yet consider this technology due to insufficient technological knowledge in the field. Undoubtedly, the concept is sensible and forward-looking, but we should bear in mind that one a large number of charging stations are established, as required by the law, but the number of electric vehicles is insufficient, it is going to be difficult to build new charging stations based on the new technology. This will eventually create a development barrier resulting from the desire to expedite electromobility in the country, and it will indirectly prevent deployment of the latest technology. At this early stage of development, utility companies are not able to adjust their business models to new emerging technologies.

\subsection{Social factors}

As regards the expansion of the charging infrastructure, for charging stations to be profitable, they need to attract as many active customers as possible to ensure that chargers operate continuously. Two main barriers can be distinguished. Firstly, the current cost of electric vehicles is significantly higher than traditional combustion ones. Secondly, another issue is the absence of tangible advantages of buying electric vehicles (economic viability, range issue etc.). As regards the number of charging sessions and social barriers, yet another important problem is the fact that almost $80 \%$ of charging sessions are performed by drivers at or close to their homes (GreenWay Poland 2017). From the point of view of the vehicle owner, it is convenient and economically justified, lower night tariffs ensure that the traveling cost is very competitive. Therefore, the fact that the law requires power utilities to build public charging stations various parts of the city is questionable. Perhaps it might be worth considering a state support scheme from the same source of funding to be used by potential customers to build such infrastructure close to their homes, and only some of them on roads between cities and in city centers to promote seamless traveling throughout the country.

\subsection{Legal factors}

The Electromobility Act is a vital first step toward the development of the electromobility market. However, attention should be drawn to some elements that need to be clarified or supplemented, including rates for the lease of land (at present, rates may differ significantly depending on the location and the approach of local governments varies), cooperation between the DSOs, 
as owners of charging stations, and electricity provider, acting as the CSO (at present, there are no explicit regulations governing cooperation between the parties), and the schedule for building charging stations until the end of 2020. A major challenge for the DSOs is to meet stringent statutory requirements in the time frame provided due to highly bureaucratic and time consuming procedures related to the purchase of equipment and construction of public charging stations.

As it was presented, there are a lot of factors affecting the implementation of electromobility projects, as well as the construction of target business models in this area. From an economic point of view, the main obstacle turns out to be high investment outlays, which translates into the need for external financial support. On the other hand, the basic operational factor is the adaptation of the appropriate pace of construction of the charging infrastructure correlated with the increase in the number of electric vehicles traveling under the country's roads. This factor also has an impact on the technical aspect related to the need to adapt the National Power System to the gradually increasing number of charging stations for electric vehicles. The social sphere is one of the most influential factors for the development of the electromobility segment. They are determined primarily by the high cost of buying an electric car, which clearly slows down the development of this area. The statutory obligations imposed on energy groups will undoubtedly speed up the segment's expansion, while the vagueness of a number of provisions and the various interpretations will be problematic for all the stakeholders.

\section{Summary}

The implementation of measures supporting electromobility can offer great opportunities for the development of the Polish power sector. We should bear in mind, however, that the promotion of the trend and the preparation of the legal framework are not sufficient for the efficient implementation of proposed solutions. First and foremost, the development of electromobility requires joint actions of Polish utilities, central administration, local governments and businesses to produce the best synergies possible. There are a number of factors, discussed in the article, which constitute barriers to the development of energy companies. However, the barriers may be overcome. To fulfill obligations imposed by the law more efficiently and promote sustainable development of competences in the area of electromobility, it is necessary to find innovative solutions that take a business model of a power company and its know-how into account. It is also clear that in order to achieve the objectives, close cooperation is necessary between all actors involved. The cooperation will effectively identify challenges on the power market and help to meet them. 


\section{References}

Almoterm SA. Analysis of the state of development and current development trends in electromobility applications in Poland. Final report (Analiza stanu rozwoju oraz aktualnych trendów rozwojowych wobszarze elektromobilności w Polsce. Raport końcowy), p. 70 (in Polish).

BernaCiaK, P. 2020. What does fuel and energy concerns invest in? ( $W$ co inwestuja koncerny paliwowo -energetyczne?) [Online] https://wysokienapiecie.pl/24520-w-co-inwestuja-koncerny-paliwowo-energetyczne/ [Accessed: 2020-02-27] (in Polish).

Besa. Deutschland vs. Poland in carsharing (Niemcy vs. Polska $w$ carsharingu). [Online] https://autonaminuty.org/niemcy-vs-polska-w-carsharingu/ [Accessed: 2020-02-20] (in Polish).

Chojnacki, I. 2020. President of GreenWay Polska: Intervention construction of charging stations is the last resort (Prezes GreenWay Polska: Interwencyjna budowa stacji ładowania to ostateczność) [Online] https://www.wnp.pl/motoryzacja/prezes-greenway-polska-interwencyjna-budowa-stacji-ladowania-to -ostatecznosc,367534.html [Accessed: 2020-02-20] (in Polish).

CIRE.PL. Electric car charging points are an investment in the future (Punkty ladowania samochodów elektrycznych sa inwestycja w przyszłość). [Online] https://www.cire.pl/item,169329,1,0,0,0,0,0,punkty-ladowania-samochodow-elektrycznych-sa-inwestycja-w-przyszlosc.html [Accessed: 2020-02-20] (in Polish).

Derski B. 2020. PGE acquires 4Mobility carsharing. They will rent cars for minutes (PGE przejmuje carsharing 4Mobility. Będzie wynajmować auta na minuty).[Online] https://wysokienapiecie.pl/18993-pge-przejmuje-carsharing-4mobility-bedzie-wynajmowac-auta-na-minuty/ [Accessed: 2020-02-20] (in Polish).

European Alternative Fuels Observatory https://www.eafo.eu/vehicles-and-fleet/m1\# [as on 2020-02-21] $\mathrm{https}$ ///leonardo-energy.pl/doplaty-z-funduszu-niskoemisyjnego-transportu-do-zakupu-e-aut-nie-beda -takie-jak-zakladano/ [Accessed: 2020-02-20] (in Polish).

GreenWay Polska. Electric vehicle charging infrastructure, city guidelines (Infrastruktura tadowania pojazdów elektrycznych, wytyczne dla miast). pp. 15-17 (in Polish).

GreenWay Polska. Electric vehicle charging infrastructure, city guidelines (Infrastruktura ładowania pojazdów elektrycznych, wytyczne dla miast). p. 23 (in Polish).

Enea Group. Strategy for the development of the Enea Capital Group until 2030 with the perspective towards 2035. [Online] https://ir.enea.pl/pr/476441/zatwierdzenie-strategii-rozwoju-grupy-kapitalowej-enea-do-2030-roku-z-perspektywa-2035-roku [Accessed: 2020-02-20].

Innogy 2017. Motorway to electromobility (Autostrada do elektromobilności). p. 16 (in Polish).

Innogy launches the first in Warsaw and the largest in Poland all-electric car sharing (Innogy uruchamia pierwszy w Warszawie i największy w Polsce, w pelni elektryczny car sharing). [Online] https://www.innogy.pl/pl/dla-mediow/2019/innogy-uruchamia-pierwszy-w-warszawie-i-najwiekszy-w-polsce-w-pelni-elektryczny-car-sharing [Accessed: 2020-02-20] (in Polish).

KŁos, M. 2020. Electromobility in Poland - development of electromobility and related challenges for the power system (Elektromobilność w Polsce - rozwój elektromobilności i zwiazane z tym wyzwania dla systemu elektroenergetycznego). [Online] https://www.muratorplus.pl/technika/elektroenergetyka/ elektromobilnosc-w-polsce-rozwoj-elektromobilnosci-wyzwania-dla-systemu-elektroenergetycznego-aa-t7oE-F5pC-pUTk.html [Accessed: 2020-02-20] (in Polish).

KRотоsкi, M. 2018. Are profits from electric car chargers acceptable? (Czy zyski z ładowarek samochodów elektrycznych sa dopuszczalne?) [Online] https://moto-prawo.pl/zyski-z-ladowarek-samochodow-elektrycznych-dopuszczalne [Accessed: 2020-02-25] (in Polish).

KURZEMPA, A. 2018. The development of electromobility - what does it really mean? (Rozwój elektromobilności - co tak naprawdę oznacza?) Autobusy - Technika, Eksploatacja, Systemy transportowe 06/2018, p. 894 (in Polish). 
Mobile City i Smartride.pl. 07/2019. On the threshold of breakthrough - shared mobility in Poland (Na progu przełomu - współdzielona mobilność w Polsce). p. 82 (in Polish).

Money.pl. 2020. PGZ and Autosan have an agreement with PGE, Tauron and Enea on the development of e-mobility (PGZ i Autosan maja porozumienie z PGE, Tauronem i Enea ws. rozwoju e-mobilności). [Online] https://www.money.pl/gielda/pgz-i-autosan-maja-porozumienie-z-pge-tauronem-i-enea-wsrozwoju-e-mobilnosci-6431117248309377a.html [Accessed: 2020-02-20] (in Polish).

PSPA 2018. Report - Electric vehicles as an element of power networks (Raport-Pojazdy elektryczne jako element sieci elektroenergetycznych). pp. 15-19 (in Polish).

Public Transport. Wrocław. Vozilla ends its activities (Vozilla kończy działalność). [Online] https://www. transport-publiczny.pl/wiadomosci/wroclaw-vozilla-konczy-dzialalnosc-63612.html [Accessed: 2020-02-20] (in Polish).

PWC. Five trends transforming the automotive industry. PWC Report pp. 6-8.

Rudyszyn, P. 2020. Electromobility in industry (Elektromobilność w przemyśle). [Online] https://globenergia.pl/magazyn/elektromobilnosc-w-przemysle/ [Accessed: 2020-02-20] (in Polish).

Scientific editing Wojciech Drożdż, 2018. Electromobility in urban development (Elektromobilność w rozwoju miast). Polish Scientific Publishers PWN, pp. 33-34 (in Polish).

SzYDLOwSKI, K. 2020. Electromobility Act: what and for whom does it change? (Ustawa o elektromobilności: co i dla kogo zmienia?) [Online] https://www.teraz-srodowisko.pl/aktualnosci/ustawa-o-elektromobilnosci-co-i-dla-kogo-zmienia-4517.html [Accessed: 2020-02-20] (in Polish).

Tauron 2020. Pilot carsharing of electric vehicles is starting in Katowice (W Katowicach rusza pilotażowy carsharing pojazdów elektrycznych). [Online] https://media.tauron.pl/pr/412317/w-katowicach-rusza-pilotazowy-carsharing-pojazdow-elektrycznych [Accessed: 2020-02-20] (in Polish).

The Economic Advisers Team TOR. Electromobility in Poland - development perspectives, opportunities and threats (Elektromobilność w Polsce - perspektywy rozwoju, szanse i zagrożenia). The Economic Advisers Team TOR, Warszawa, p. 26 (in Polish).

The European Copper Institute. Subsidies from the Low Emission Transport Fund to buy e-cars will not be as expected (Dopłaty z Funduszu Niskoemisyjnego Transportu do zakupu e-aut nie będa takie, jak zaktadano) (in Polish).

The Ministry of State Assets 2020. Electromobility in Poland (Elektromobilność w Polsce). [Online] https:// www.gov.pl/web/aktywa-panstwowe/elektromobilnosc-w-polsce [Accessed: 2020-02-20] (in Polish).

The Ministry of State Assets. The government adopted the National Policy framework for the Alternative Fuel Infrastructure (Rząd przyjąt krajowe ramy polityki rozwoju infrastruktury paliw alternatywnych). [Online] https://www.gov.pl/web/aktywa-panstwowe/rzad-przyjal-krajowe-ramy-polityki-rozwoju-infrastruktury-paliw-alternatywnych-3 [Accessed: 2020-02-20] (in Polish).

The Ministry Development Funds and Regional Policy. Information about the Responsible Growth Strategy (Informacje o strategii na rzecz odpowiedzialnego rozwoju). [Online] https://www.gov.pl/web/ fundusze-regiony/informacje-o-strategii-na-rzecz-odpowiedzialnego-rozwoju [Accessed 2020-02-20] (in Polish).

WitKowsKi, Ł. and WiŚNIEwSKI, J. 2018. The Electromobility and Alternative Fuels Act. Warszawa: PSPA the Polish Alternative Fuels Association, pp. 34-35. 


\title{
Problemy rozwoju elektromobilności z perspektywy polskich grup energetycznych
}

\author{
Streszczenie
}

\begin{abstract}
Elektromobilność w chwili obecnej jest segmentem bardzo dynamicznie rozwijającym się i jednocześnie posiadającym wiele niewiadomych, z którymi muszą się zmierzyć przedsiębiorstwa chcące rozwijać ten obszar w swoich strukturach. Niniejszy artykuł ma na celu przybliżenie pojawiających się problemów podczas rozwijania elektromobilności z perspektywy polskich grup energetycznych, które z tym obszarem są ściśle powiązane, chociażby przez nałożone obowiązki ustawowe. Elektryfikacja transportu stała się już faktem i aby wykorzystać jej potencjał na rozwój nowych usług czy wdrożenie innowacji i nowych technologii, należy zidentyfikować bariery rozwojowe i przygotować na nie gotowy plan odpowiedzi. Autorzy artykułu postanowili w pierwszej kolejności wykazać implikacje formalno-prawne dla rozwoju segmentu elektromobilności w kraju, a następnie zbadać strategie rozwoju polskich grup energetycznych pod kątem elektromobilności oraz wskazać eksplorowane obszary z tym związane. Kolejny podrozdział koncentruje się na wskazaniu głównych barier implementacji modeli biznesowych, klasyfikując je według następujących czynników: ekonomicznych, operacyjnych, technicznych, społecznych i prawnych. Takie przedstawienie problematyki pozwala na wnikliwe rozpoznanie zagadnienia i uświadomienie, że w celu osiągnięcia założonych przez ustawodawcę celów, niezbędna jest ścisła współpraca wszystkich interesariuszy, zarówno na szczeblu krajowym, jak i lokalnym, jednocześnie angażując $\mathrm{w}$ te działania grupy energetyczne, przedsiębiorstwa finansowe, producentów pojazdów elektrycznych, a przede wszystkim jednostki samorządów terytorialnych.
\end{abstract}

SŁOWA KLUCZOWE: paliwa alternatywne, sektor energetyczny, elektromobilność, czysty transport 